\title{
President's Welcome
}

\author{
James Bullard
}

4

s president of the Bank, it is my pleasure to welcome you to the ThirtyThird Annual Policy Conference of the Federal Reserve Bank of St. Louis. This conference concerns measurement of the economy's potential output. The concept of potential output is straightforward to define-the economy's maximum sustained level of outputbut difficult to measure. Inclusion of the term sustained suggests that the concept of potential growth is closely tied to inflation-a low, stable inflation rate is essential if an economy is to attain maximum economic growth and, hence, remain through time at or near its potential level of output.

In macroeconomic stabilization theory and practice, the concept of potential growth has a long history. Early analyses focused on the output gap. Fortunately, belief in an exploitable long-run tradeoff between the unemployment rate and the rate of inflation was rejected by economists decades ago. Today's classical and New Keynesian models suggest that, given enough time for adjustment and a benign pattern of shocks, the economy will adjust in the long run toward its potential level of output. The speed of such adjustment depends on the relative flexibility or inflexibility of wages, prices, and expectations-aptly summarized by Keynes's quip that "In the long run, we are all dead." But, taken literally, Keynes's call to action, as we now recognize, can be quite dangerous when near-term preliminary data contain significant uncertainty and measure- ment error, as demonstrated by the papers of Athanasios Orphanides, John Williams, and Simon van Norden (e.g., Orphanides and van Norden, 2002; and Orphanides and Williams, 2005).

The concept of potential output is an important feature of monetary policymaking. At our conference in 2007 in honor of Bill Poole, Lars Svensson and Noah Williams (2008, p. 275) characterized the task of policymakers as seeking to "navigate the sea of uncertainty." Correct economic stabilization policy, like correct navigation, requires a focus on the destination, or long-run objective. The Federal Reserve, in particular, operates with a dual mandate from the Congress to achieve both price stability and maximum employment. These goals are not in conflict_-both require fostering an environment to support maximum sustainable growth. Academic policy models, while differing one from another, typically include a concept of potential output. Fixed-parameter policy rules, such as the Taylor rule, feature an output gap. Flexible inflation targeting models, such as those of Lars Svensson (e.g., Svensson, 1997) emphasize that inflation can, and does, at times, move away from the desired level. Thus, the choice of an optimal policy that will return inflation to its target depends on a tradeoff between the costs of the higher-but-falling inflation and any induced output gap (i.e., an output gap judged relative to some measure of potential output). One lesson of such models is that, even when monetary policymakers focus solely on achieving price

James Bullard is president of the Federal Reserve Bank of St. Louis.

Federal Reserve Bank of St. Louis Review, July/August 2009, 91(4), pp. 179-80.

(C) 2009, The Federal Reserve Bank of St. Louis. The views expressed in this article are those of the author(s) and do not necessarily reflect the views of the Federal Reserve System, the Board of Governors, or the FOMC. Articles may be reprinted, reproduced, published, distributed, displayed, and transmitted in their entirety if copyright notice, author name(s), and full citation are included. Abstracts, synopses, and other derivative works may be made only with prior written permission of the Federal Reserve Bank of St. Louis. 
stability, the path of the output gap will enter into their deliberations regarding an optimal policy to reach that goal.

It is in this spirit of the important policy role of potential output that I welcome the speakers who will share their thoughts with us. We are particularly rich in speakers from abroad, bringing a distinct international focus to our discussions. I trust we will all increase our understanding of the concept of potential output and its role in policymaking.

\section{REFERENCES}

Orphanides, Athanasios and van Norden, Simon.

"The Unreliability of Output Gap Estimates in Real Time." Review of Economics and Statistics, November 2002, 84(4), pp. 569-83.

Orphanides, A. and Williams, John C. "Expectations, Learning, and Monetary Policy." Journal of Economic Dynamics and Control, November 2005, 29(11), pp. 1807-08.

Svensson, Lars E.O. "Optimal Inflation Targets, 'Conservative' Central Banks, and Linear Inflation Contracts." American Economic Review, March 1997, 87(1), pp. 98-114.

Svensson, Lars E.O. and Williams, Noah. "Optimal Monetary Policy Under Uncertainty: A Markov Jump-Linear-Quadratic Approach.” Federal Reserve Bank of St. Louis Review, July/August 2008, 90(4), pp. 275-93. 